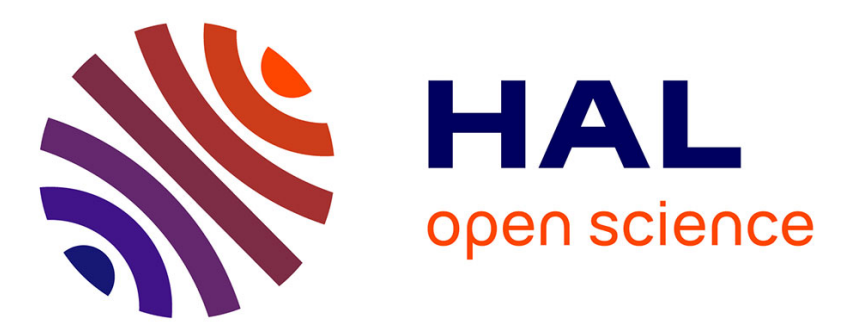

\title{
Periglacial morphogenesis in the Paris Basin: insight from geophysical survey and consequences for the fate of soil pollution.
}

Médard Thiry, Fok van Oort, Julien Thiesson, Brigitte van Vliet-Lanoë

\section{- To cite this version:}

Médard Thiry, Fok van Oort, Julien Thiesson, Brigitte van Vliet-Lanoë. Periglacial morphogenesis in the Paris Basin: insight from geophysical survey and consequences for the fate of soil pollution.. Geomorphology, 2013, 197, doi: 10.1016/j.geomorph.2013.04.027. 10.1016/j.geomorph.2013.04.027 . hal-00818938

\section{HAL Id: hal-00818938 \\ https://hal-mines-paristech.archives-ouvertes.fr/hal-00818938}

Submitted on 29 Apr 2013

HAL is a multi-disciplinary open access archive for the deposit and dissemination of scientific research documents, whether they are published or not. The documents may come from teaching and research institutions in France or abroad, or from public or private research centers.
L'archive ouverte pluridisciplinaire HAL, est destinée au dépôt et à la diffusion de documents scientifiques de niveau recherche, publiés ou non, émanant des établissements d'enseignement et de recherche français ou étrangers, des laboratoires publics ou privés. 
NOTICE: this is the author's version of a work that was accepted for publication in Geomorphology. Changes resulting from the publishing process, such as peer review, editing, corrections, structural formatting, and other quality control mechanisms may not be reflected in this document. Changes may have been made to this work since it was submitted for publication. A definitive version was subsequently published in:

Geomorphology, 2013, DOI: 10.1016/j.geomorph.2013.04.027

\title{
Periglacial morphogenesis in the Paris Basin: insight from geophysical survey and consequences for the fate of soil pollution
}

\author{
Médard Thiry ${ }^{1}$, Folkert van Oort ${ }^{2}$, Julien Thiesson ${ }^{3}$, Brigitte Van Vliet-Lanoe ${ }^{4}$
}

${ }^{1}$ Mines-ParisTech, Géosciences, 35 rue St. Honoré, 77305 Fontainebleau cedex, France, medard.thiry@mines-paristech.fr

2 INRA, UR251 Pessac, RD-10, 78026 Versailles cedex, France, vanoort@versailles.inra.fr

${ }^{3}$ Université Pierre et Marie Curie, UMR 7619 Sisyphe, case 105, 4 pl. Jussieu, 75252 Paris, France

${ }^{4}$ Université de Brest, UMR 6538 Domaines Océaniques, place Copernic, 29280 Plouzané, France

\section{Keywords:}

periglacial, cryoturbation, soils, geophysical method, electrical mapping, pollution, micromorphology, pedology,

Artist view of the cryogenic infolded clay structures below the black strip of the polluted soils of the dismal Pierrelaye Plain, by the author (MT)

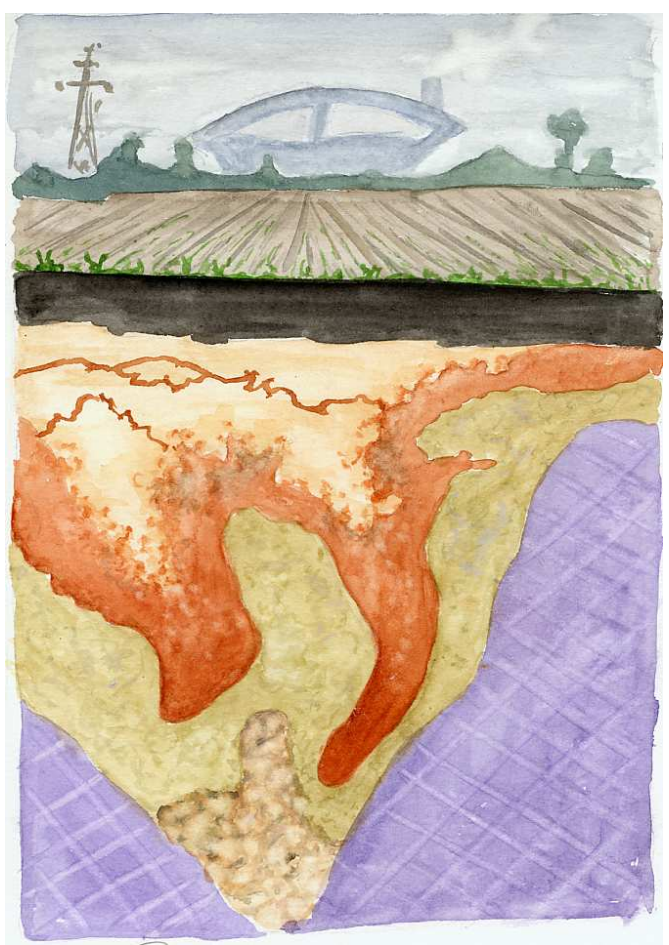




\section{Abstract:}

Geophysical survey by Automatic Resistivity Profiling system (ARP ${ }^{\odot}$ ) of the PierrelayeBessancourt area revealed remarkable conductive polygon patterns of 20-30 m diameter detected between 0.5 and $1.7 \mathrm{~m}$ depth. Trenches dug down to the limestone substrate allowed detailing of the pedological and lithological units that compose such polygonal features. The patterns are formed by greenish glauconite and carbonated sand hollows where clay-rich pedological horizons bend downward, forming narrow tongs extending up to 2-3 m depth. Such structures were interpreted as a buried polygonal ice-wedge network (thermokarst depressions). Geometrical relationships between the lithological units and consecutive erosional surfaces allowed the identification of successive landscape events and a landscape chronology. The sequence started during the Saalian glaciation with (1) development of patterned grounds by thermokarstic cryoturbation; (2) consecutive deflation/erosion during post-permafrost aridity; (3) loess and eolian sand deposits; (4) weathering of the former deposits with development of pedogenic horizons during the Eemian interglacial; (5) recurrent cryoturbation and thermal cracking leading to infolding of the pedogenic horizons during the Pleniglacial optimum (Weichselian); (5) finally erosion that levelled the periglacial microreliefs, most probably during the last glacial stage (Weichselian); leading to the modern landscape. In this agricultural area, urban waste water has been spread for more than 100 years by flooding irrigation for food crop production, and has led to high levels of metal pollution in the surface horizons of the soils. The polygonal cryogenic structures have major impacts on soil hydrology and dispersion/distribution of heavy metals toward the geological substrate. Such structures are essential to consider when conceiving proposals for future soil management of this polluted area.

\section{Introduction}

European landscape and especially the Paris basin was located in a zone of continuous permafrost extent (Dylik \& Maarleveld, 1976; Van Vliet-Lanoë \& Hallégouët, 2001) during the last glaciation, which probably extended further south during the coldest part of the Middle Pleistocene - Marine Isotopic Stages (MIS) 12 and 10. MIS 8 (Saalian II) is brief but very cold and arid, whereas the MIS 6 (Saalian III) is much less arid and colder toward its end (Seidenkrantz et al., 1996). Common traces for permafrost occurrences are the development of metric polygonal patterns due to ground thermal contraction (Dylik \& Maarleveld, 1976; 
Washburn, 1979). Usually thermal contraction proceeds in ice-rich sediment due to abrupt temperature drop (Lachenbruch, 1962; Allard \& Kasper, 1998). During glacial times,

European permafrost is generally ice-poor (Van Vliet-Lanoë \& Hallégouët, 2001) and thermal cracking only proceeds on depressions fed by lateral slope seepage, for example from a sandy reservoir and by snowmelt supply. Moreover, patterned grounds such as stone circles (Washburn, 1979) are common on limestone affected by ice-rich permafrost, promoting frost shattering in the active layer.

In the Pierrelaye-Bessancourt area, located north-west of Paris, evidence of patterned ground and polygonal structures appear sporadically in aerial views during dry years. A pedological soil survey campaign in this area, based on soil auger drilling and soil pits (Bourennane et al., 2006; Dère et al., 2006) revealed a great variability of soil depth and contrasting situations with local zones with thicker and deeper clay-rich horizons (van Oort et al., 2008). Hence, the aim of the present work was to assess the spatial extension of these soil structures over the entire area and to examine whether they were linear, related to faults, or had a more isotropic distribution. For this, geophysical survey techniques were first used, being most suitable to detail the spatial distribution of such structures, followed by trench diggings in order to correlate geophysical properties with pedomorphological information. We successively show the geometries revealed by the geophysical survey, describe the sections that correspond to these structures, interpret them in terms of periglacial processes, and finally discuss how this geomorphology leads to specific soil features and pedogenetic processes, influencing the fate of recent anthropogenic soil pollution.

\section{Site and methods}

The Pierrelaye-Bessancourt area, covering about 1200 ha, is located $30 \mathrm{~km} \mathrm{NW}$ of Paris, in the triangle formed by the confluence of the Seine and Oise rivers. It is formed of 2 distinct geomorphological units: a lower plateau corresponding to the middle Eocene 'Marnes et Caillasses' Limestone Formation, and an upper plateau sustained by the St.-Ouen Limestone Formation of upper Eocene age. The two plateaux are separated by a $40 \mathrm{~m}$-high scarp formed by the Beauchamp Sandstone Formation (Fig. 1). Topography of the plateaux is very regular and smooth with an average slope angle of about 1\%. From about 1890 until 2000, this area was used for intensive spreading of urban wastewater, applied by flooding irrigation to produce food crops. 

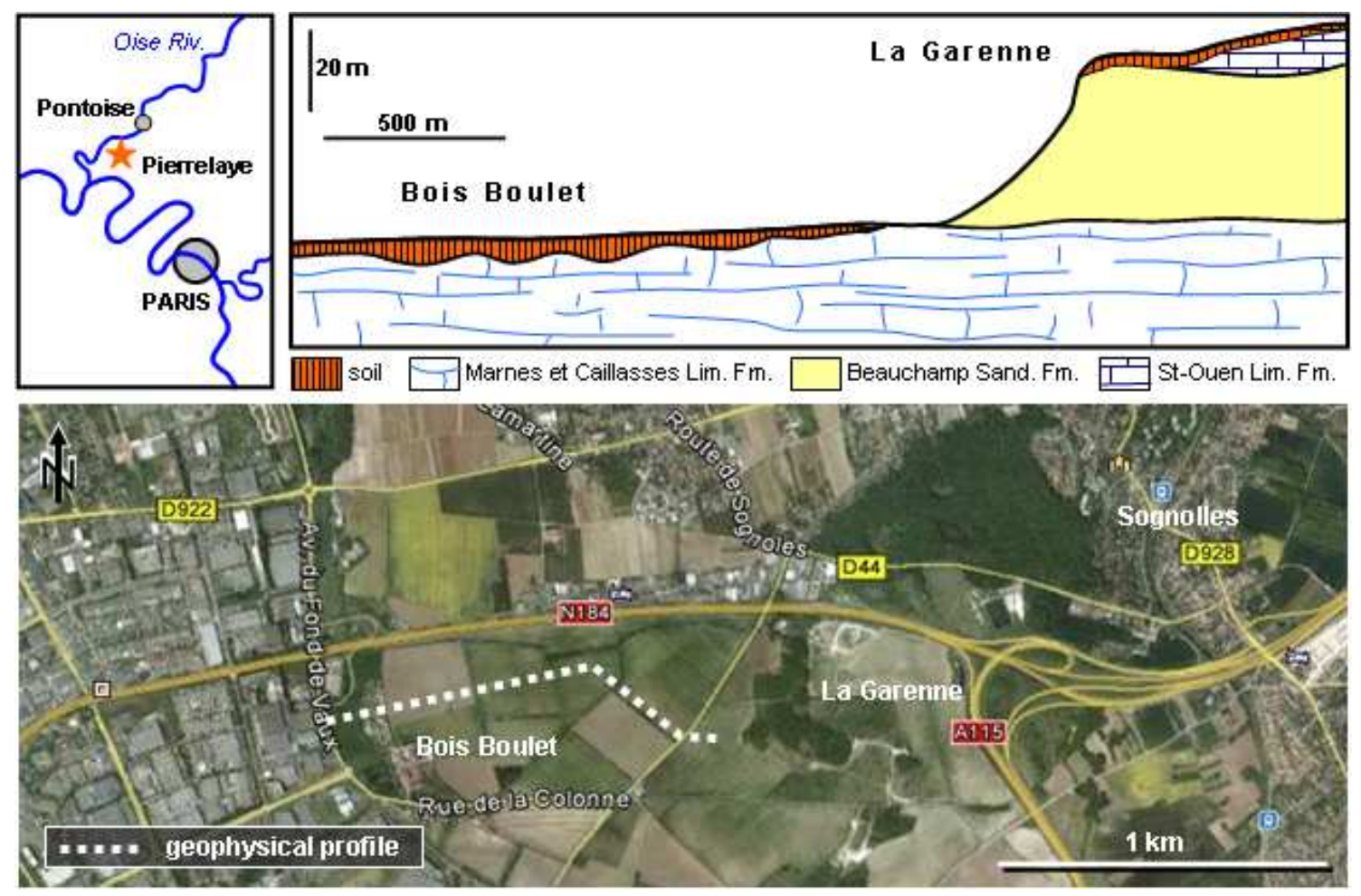

Figure 1 - Situation the Pierrelaye-Bessancourt area and geological sketch through the plateaux and Google Earth aerial photograph with trace of the geophysical survey.

Geophysical survey was done by the electric resistivity method, which is well suited to noninvasive description of soil subsurface structure (Tabbagh et al., 2000) and to achieve insight into soil thickness variations by means of multi-depth continuous profiling (Dabas, 2008). Resistivity mapping was done at three depths $(0-0.5 \mathrm{~m}, 0-1.0 \mathrm{~m}$, and 0-1.7 $\mathrm{m}) \mathrm{u}$ sing the $\mathrm{ARP}^{\odot}$ (Automatic Resistivity Profiling) system. The multi-electrode device was driven with a quad bike. The on-board computer registered the measures and GPS positions. Such a device allowed the analysis of about 16 ha of farmland per day. Complementarily, aerial photographs were explored on Google Earth in order detect and estimate the extent of the polygonal features seen by geophysical methods.

Trenches were dug for pedological study. They were sunk until the hard limestone was reached, from about 0.6 to $3.5 \mathrm{~m}$ depth. Finally, 6 trenches were investigated, representing a total length of about $250 \mathrm{~m}$. All sections were surveyed by means of general description of macromorphology and thickness of soil layers, whereas specific locations were sampled in detail for micromorphological, mineralogical and geochemical studies. 


\section{$3 \quad$ Results and discussion}

\subsection{Polygonal features}

\subsubsection{Electrical mapping}

Geophysical survey using electrical mappings revealed remarkable linear and interconnected conductive features organised in decametric (about 20-40 m) polygonal-shaped patterns (Fig. 2). Such conductive anomalies were about 2 to $3 \mathrm{~m}$ wide. The depth of the patterns varied: on electrical mappings, the polygon structures were visible locally for the shallower measurements $(0-0.5-\mathrm{m}$ depth). Yet, in the prospected area they were most clearly detected when exploring greater depths $(0.5-1.7 \mathrm{~m})$. The deepest structures were the most lithologically contrasted. Highly conductive structures (darker in Fig. 2) coincided with more moist and/or more clayey materials, whereas less conductive structures (whiter in Fig. 2) corresponded to more sandy and/or blocky limestone materials.

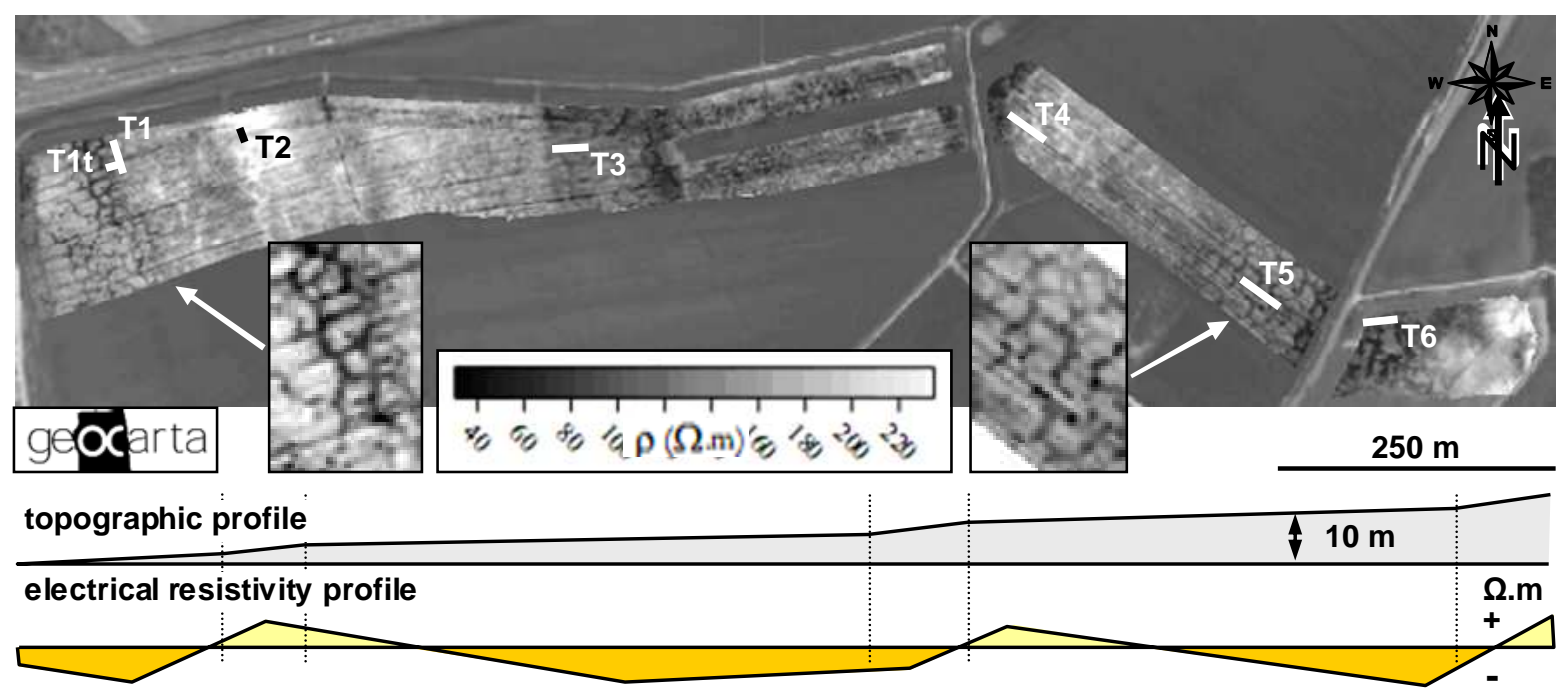

Figure 2 - Electrical resistivity map of the Bois Boulet area, performed between the surface and 1.0-m depth obtained with APR@ (Automatic Resistivity Profiling) method. Notice the detail of the regular polygonal shaped patterns of about $20-30 \mathrm{~m}$ in diameter. The zones with an overall higher resistivity (light) prevail up slop of the topographic breaks, the polygonal patterns with lower resistivity (dark) occur mainly down the topographic breaks. (Tn) Position and extend of trenches dug on the parcels.

The resistivity maps also revealed relationships between more or less resistive zones and the topography of the parcels. The zones of low resistivity corresponded to the flattest profiles, whereas the most resistive zones were in relation with slope breaks, rather up-slope (Fig. 2). This slope/resistivity relationship was more obvious for the more shallow depth conductivity maps. 
The polygonal patterns were of two types: in general, the polygonal structures were conductive (dark) with a less conductive core (light); yet, some zones showed polygonal structure with a reversed contrast, with a less conductive network and more conductive core. This latter disposition was particularly observed in the less conductive zones.

\subsubsection{Aerial photographs}

Relatively dry plough zones and subsurface features were visible on some aerial photo campaigns. Among 7 aerial photo campaigns available on Google Earth, between 2002 and 2011, two photographs, dating from March $27^{\text {th }} 2002$ and January $1^{\text {th }} 2011$, show blurred and discontinuous polygonal features (Fig. 3), but only on some parts of the fields, and not always on the same locations. Resolution of the aerial photographs is much less sharp and contrasted than pictures obtained with $\mathrm{APR}^{\odot}$ electrical resistivity map. Nevertheless, aerial photos may provide additional information on the distribution of the polygonal features on the PierrelayeBessancourt area, but obviously their detection depends on various factors, such as the vegetation cover, the timing of the aerial photographs, and textural characteristics of the soil cover. Locally, polygonal features show up on the whole area, both on the lower plateau, corresponding to the middle Eocene limestone formation where the Bois Boulet fields are situated, as well as on the upper plateau supported by the upper Eocene limestone (Fig. 1).

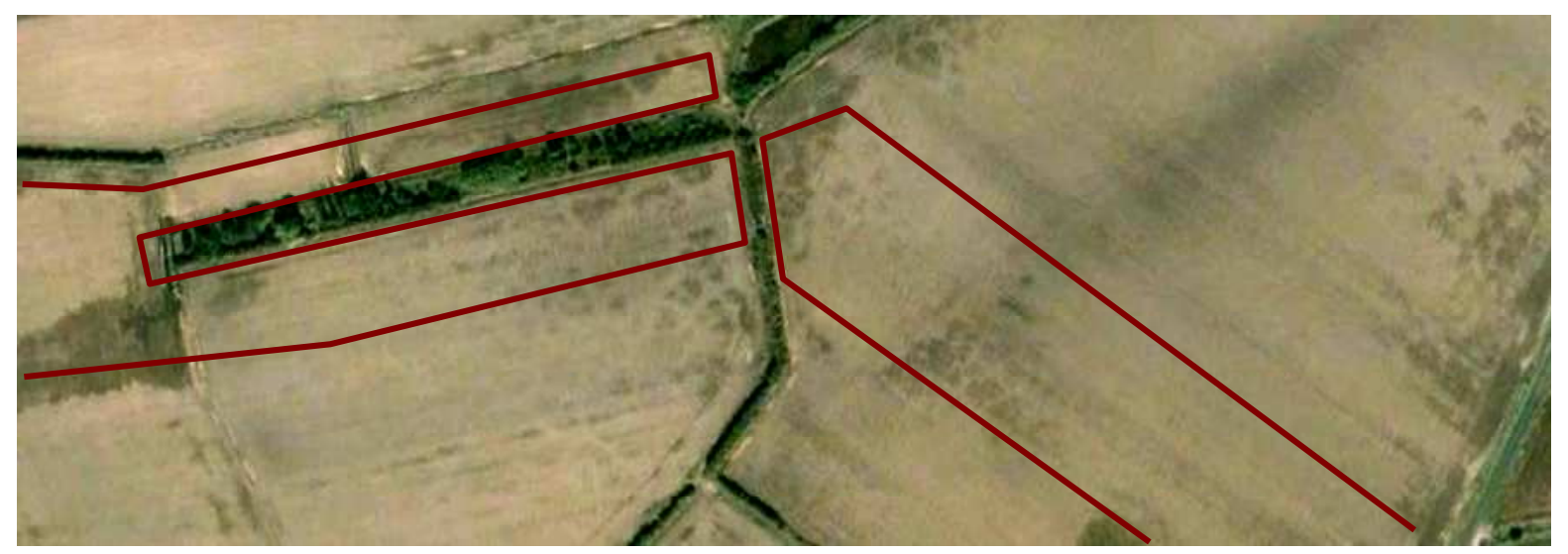

Figure 3 - Aerial photograph (27/03/2002) from the Bois Boulet studied area showing blurred and discontinuous polygonal features by differential drying of the plug horizon. White lines delimit the zones covered by the electrical resistivity map (Fig. 2).

\subsection{Soil and sand-sink structures}

Trenches were dug down to the middle Eocene limestone in order to precisely locate the pedological and lithological units that form the polygonal features. Hereafter, we first present a general description, then their specific arrangements. 


\subsubsection{The soil profile}

From the surface to depth, the soils are composed of three main pedological horizons overlying the stony and/or sandy calcareous geological substrate (Fig. 4).

- Ap horizon - plough layer of varying thickness, generally from about $30 \mathrm{~cm}$ to locally more than $60 \mathrm{~cm}$ thickness, sandy textured with a characteristic dark brown to black colour due to the accumulation of large amounts of organic matter added by long-term irrigation with urban waste water.

- E horizon - eluvial (leached) layer; sandy textured with generally $<5 \%$ clay, displaying a beige to light brown colour, varying from less than $5 \mathrm{~cm}$ to more than 30 $\mathrm{cm}$ thickness, locally showing bow-like, about 1-cm thin iron-impregnated layers.

- Bt horizon - a clay-iron illuviated soil layer, composed of reddish-brown clayey sand, about 20 to $40 \mathrm{~cm}$ thick. Its boundary with the overlying $\mathrm{E}$ horizon is often gradual and irregular, whereas its lower limit is fairly distinct, designated as a BCca transitional horizon of about $10 \mathrm{~cm}$ thickness.

- Limestone clast lag - centimetre-sized, angular limestone clasts underline in a marked continuous way the base of the clay-rich Bt horizon. The clasts may penetrate/mix with the above clayey horizon.

- Cca layer composed of secondary carbonate accumulations locally occur discontinuously in the carbonate substrate. They are composed of powdery white calcite and develop within the glauconite-rich calcareous sands as well as within the limestone. Such carbonate accumulations form generally about $5-\mathrm{cm}$ thick horizontal elongated lenses extending up to $1 \mathrm{~m}$ length. Two ${ }^{14} \mathrm{C}$ datings produced ages of 5700 $\pm 40{ }^{14} \mathrm{C}$ years BP and $26,400 \pm 200{ }^{14} \mathrm{C}$ years BP. Because of possible limestone impurities in the small Cca layers (Thiry et al., 2011), such ${ }^{14} \mathrm{C}$ ages must be considered as maximal ages.

- Limestone substrate - the Bt horizon and limestone clast layer overly either middle Eocene limestone, quoted as Cc, or greenish glauconitic-rich carbonated sand, quoted as Cs. The Marnes et Caillasses limestone is the most widespread substrate, consisting of a hard carbonate rock, broken into decimetre-sized fragments and embedded in softer marl. The green Cs sands frequently contain hard limestone elements, and have a more restricted occurrence. 


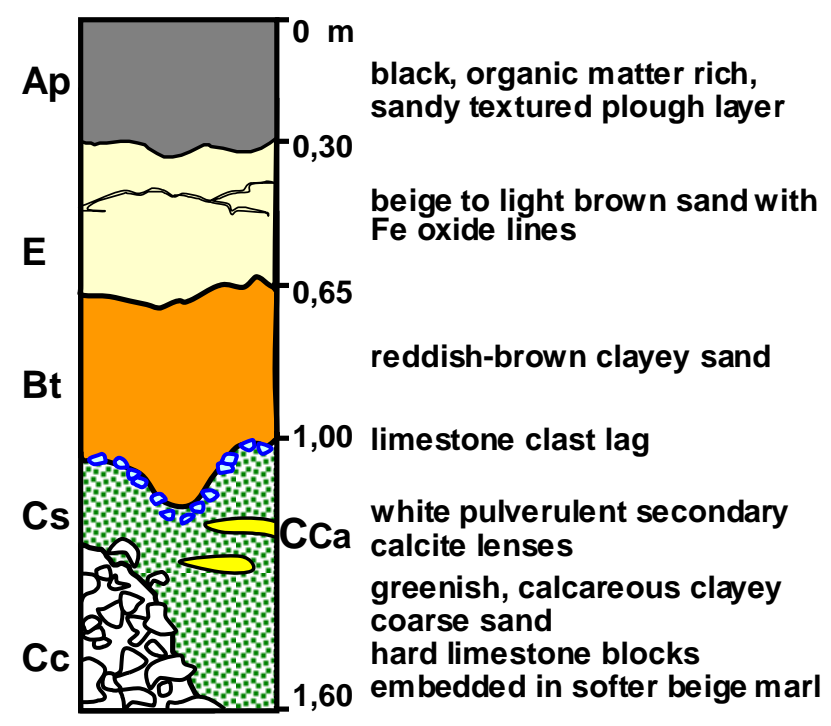

Figure 4 - Synthetic soil profile of the Pierrelaye farmland area. Some horizons and/or lithological layers may be lacking, but their mutual position in tranches remains unchanged.

\subsubsection{Sand hollows and infolded clay structures}

The trenches demonstrated typical sequences of greenish sand-filled hollows alternating with fragmented limestone of the Marnes et Caillasses bedrock (Fig. 5). Such sand hollows are discrete within the fragmented limestone, most often restricted to depressions of 2-10 m wide and 1-3 m depth. They were fairly regularly spaced with a frequency of about 15-30 m. In the overlying soil cover, both $\mathrm{E}$ and Bt horizons were particularly well-developed above the sand hollows. Between sand hollow positions, E and the Bt horizon generally showed a fairly regular thickness, but often were reduced, or even absent. The E horizon in inter-hollow position was only locally present, most often related to a deepening of the Bt horizon (Fig. 5). When the $\mathrm{E}$ and $\mathrm{Bt}$ horizons were absent, then the Ap plough horizon directly overlaid the Marnes et Caillasses bedrock (Fig. 5). Such Ap-Cc profiles corresponded to locations where the conductivity maps were most contrasted, with conductive polygons (dark) and less conductive (light) cores. Such architecture suggests a direct relationship between the conductive polygonal-shaped structures and formation of pronounced sink hollows with deep infolded clay layers.

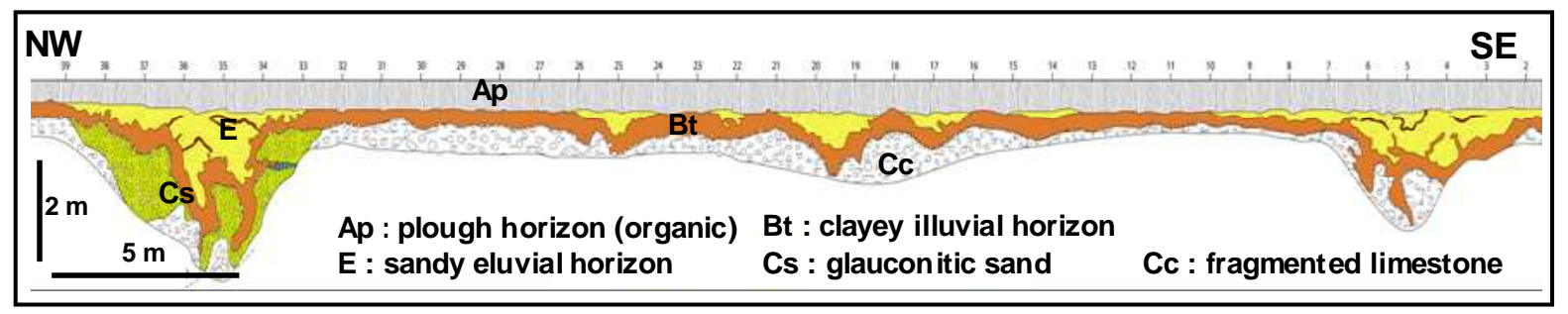

Figure 5 - Section of a $45 \mathrm{~m}$ long trench dug across the contrasted electrical resistivity polygonal structures. It shows two deep sinking hollows spaced of about $30 \mathrm{~m}$.

Downward bending E and Bt horizons were the most outstanding features visible in the trenches (Fig. 6). The deformation structures did not affect the superficial Ap horizon. They 
were characterized by an increasing thickness of the $\mathrm{E}$ and $\mathrm{Bt}$ horizons, which tongue into the greenish glauconite sand hollows (Fig. 6a, b). The clay horizon was most affected by the sink structures. The geometry of the eluviated E horizon was less modified, although its observed thickness was greatest above the sinks. Such features were of variable sizes, with small structures of about $40-50 \mathrm{~cm}$ deep, widening to the top, whereas the largest structures occurred to about 2-3-m depth in the glauconitic sand, being generally more wedge shaped (Fig. 7a, b \& c). The brecciated limestone bedrock frequently showed vertically upjacked clasts (Fig. 7e). Yet, the sink structures were most often intersected by only one trench wall (trench width of about $1 \mathrm{~m}$ ), or at least they appeared small-sized in the opposite wall, suggesting that such features had mainly cylindrical shapes $(\approx 1-2 \mathrm{~m}$ in diameter), penetrating into the greenish sand hollows and, occasionally in the fragmented limestone. But no such structures were observed penetrating further than the limestone bedrock, thus excluding that they were related to true karst pipes.

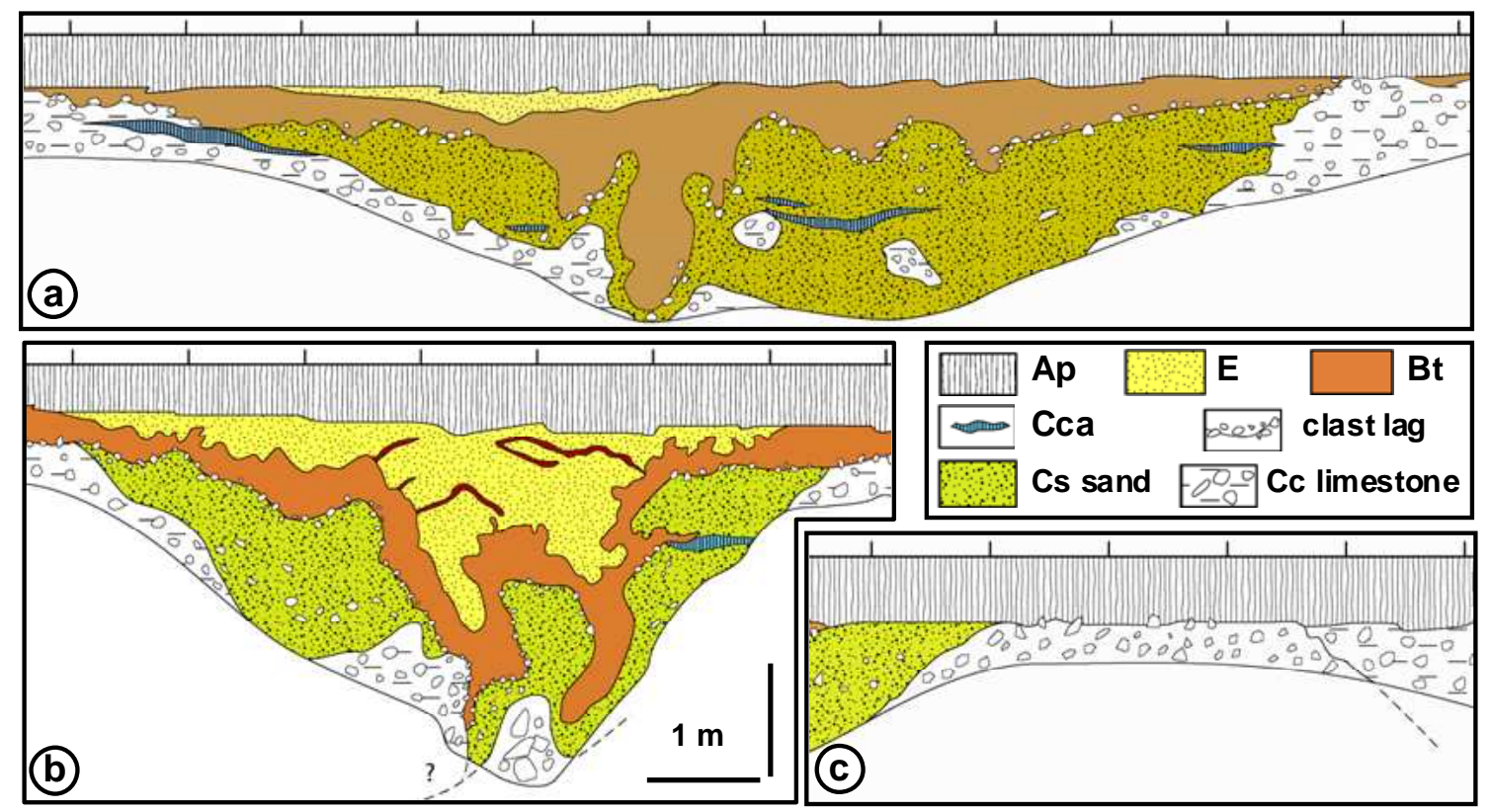

Figure 6 - Morphological characteristics of the sink structures. Such features are quasi-restricted to glauconite-rich greenish sand hollows within the fragmented limestone bedrock. Erosion occurred after development of the sink features. Ap- plough horizon; E- eluvial horizon; Bt- illuvial horizon; Csglauconitic sand; Cc- fragmented limestone.

The clast lag intimately followed the sink structure morphology, indicating that its deformation was concomitant with that of the clay Bt horizon (Fig. 7d). Such findings imply that the clast lag and the clay layer formed as horizontal lying layers, subsequently deformed by sinking, and preferentially centred with regard to the glauconite sand filled hollows, more favourable for drainage. Locally, outside sink and sand hollow situations, the Ap horizon sometimes directly overlaid the fragmented limestone (Fig. 6c, 7e). This latter configuration 
points to a truncation by an erosion of the clayey and sandy surface material, subsequent to the development of the sink features, or to incorporation of $\mathrm{E}$ and/or Bt horizons by deep ploughing - a current agronomic practice under market garden management.
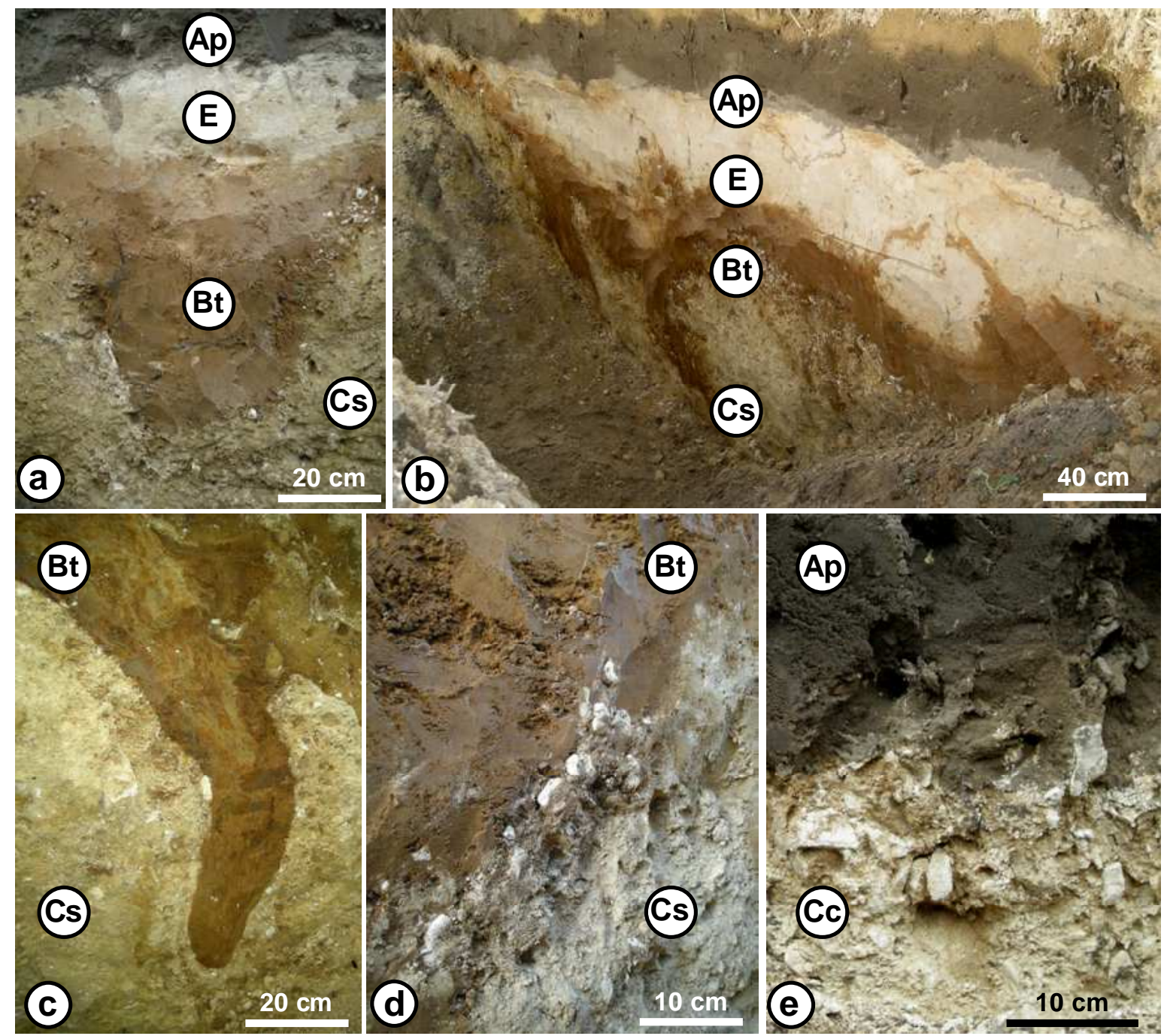

Figures 7 - Typical soil features as shown in the trenches. (a) - Small and shallow sink structure within the glauconitic sand. (b) - Major glauconitic sand hollow with three large clayey sink structures of the Bt horizon. Notice the progressive transition between $\mathrm{E}$ and Bt horizon by way of a speckled and $\mathrm{Fe}$ oxide lines within the E horizon. (c) - Detail of a narrow and deep Bt sink. Notice the small limestone clasts that border the infolding and the larger limestone blocks embedded within the Cs glauconitic sand. (d) - Details of the clast lag that underlines the Bt horizon. (e) - Plough horizon overlying the Cc fragmented limestone. Notice the vertically upjacked limestone clast embedded in a crushed limestone matrix. Ap- plough horizon; E- eluvial horizon; Bt- illuvial horizon; Cs-glauconitic sand; Cc- fragmented limestone.

The zones of contrasted resistivity shown by the geophysical survey tally with the relative disposition of $\mathrm{E}$ and $\mathrm{Bt}$ horizons. Zones of overall high resistivity correspond to thick and continuous sandy E horizon, those with general low resistivity coincide with rather continuous clayey Bt horizon and without E horizon. The zones where high resistivity forms polygonal patterns match with structures where the E horizon is restricted to sink structures. 
This is consistent with deeper and shallower erosion of $\mathrm{E}$ and Bt horizons in relation with slope breaks along the profile: the less eroded structures, with thicker sandy E horizon, prevailing up-slope, ahead of the break; the more eroded ones, with clayey Bt directly below the plough horizon, prevailing down the slope break.

\subsubsection{Micromorphology and grain-size in soil horizons}

In thin sections collected in Luvisols outside the sink positions, optical microscopy showed that the groundmass of Ap, E, Bt, and BC horizons (Fig. 8) had a common basic mineral compound composition with predominantly coarse and fine sand grains of smooth, subangular to sub-rounded quartz with additional minor amount of plagioclase and microcline feldspar as well as green-yellow glauconite. In all horizons, some coarse to very coarse (2-> 5 $\mathrm{mm})$ chert fragments occurred. Silt-sized particles $(10-50 \mu \mathrm{m})$, mainly composed of subrounded quartz were present in all horizons but in small amounts $(<15 \%)$. The $\mathrm{E}$ and $\mathrm{Bt}$ horizons differ greatly in their clay content, resulting from pedogenesis: removal by leaching of fine clay (eluviation) from the E horizon (Fig. 8b) in the percolating soil solution and its accumulation (illuviation) in the Bt horizon, where thin $(20-50 \mu \mathrm{m})$ pure, yellow-orange, translucent clay-iron coatings with strong birefringence frequently occur around the skeleton grains (Fig. 8c), and occasionally fill up simple packing voids (van Oort et al., 2008; van Oort et al., 2013). In the overlying Ap plough layer, most sand grains are coated with dark finely divides organic matter and very fine secondary carbonate crystals, added to the surface horizon by intensive waste water irrigation (Fig. 8a).

Complementary analyses of the grain-size distribution on about 130 soil samples demonstrated that the ratios between silt and sand, as well as between fine and coarse sand fractions, were remarkably constant for the Ap, E, Bt, and BCca horizons (Table 1). The carbonated substrate layers showed diverging values of granulometric ratios, notably smaller proportions of coarse sand and a larger proportion of silt-sized particles, due to the presence of consistent amounts of silt-sized carbonate particles. Such findings on the similar nature, morphology and size of soil's skeleton composition indicate a common origin of the material overlying the carbonate substrate, in which pedogenesis led to Luvisol formation. 

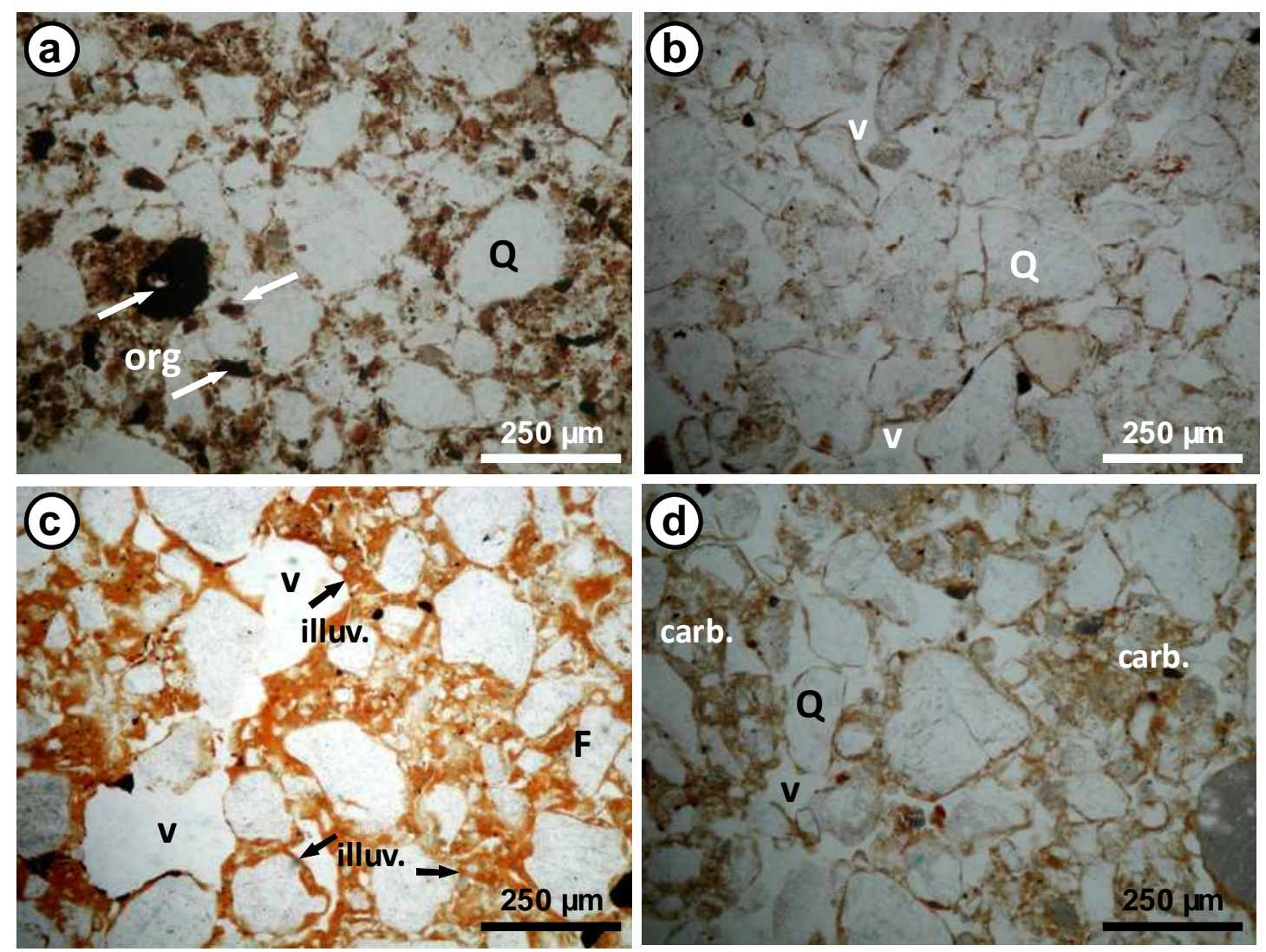

Figure 8. Optical microscope images of the groundmass of the Luvisol profile in the Pierrelaye area. (a) - Ap horizon, notice the abundance of dark organic-rich particles in the matrix. (b) - E horizon, sandy textured with very few clay bridges between the sand grains. (c) - Bt horizon, abundant clayey matrix, with large reddish-brown laminated illuviations (arrows). (d) - BCca horizon with fine calcite matrix. Size and morphology of quartz grains are very similar in all horizons. The $\mathrm{E}$ and Bt horizon differ due to respectively removal and accumulation of the clayey material. There is no significant difference of the detrital grain sizes and shapes in these horizons. F: feldspar, Q: quartz, v: void, illuv.: illuviation, carb.: carbonate. Plane polarized light.

Table 1. Silt-to-sand and fine-to-coarse sand ratios determined on samples from Ap, E, Bt, BCca horizons and from $\mathrm{Cs}$ and $\mathrm{Cc}$ carbonate substrate samples. $\mathrm{N}$ : number of samples in each horizon.

\begin{tabular}{|l|c|c|c|c|c|}
\hline horizons & $\mathrm{Ap}$ & $\mathrm{E}$ & $\mathrm{Bt}$ & $\mathrm{BCca}$ & $\mathrm{Cs}+\mathrm{Cc}$ \\
\hline $\mathrm{N}$ & 20 & 15 & 42 & 18 & 33 \\
\hline silt / sand & $0.14 \pm 0.04$ & $0.11 \pm 0.02$ & $0.10 \pm 0.04$ & $0.13 \pm 0.06$ & $0.25 \pm 0.17$ \\
\hline fine sand / coarse sand & $1.04 \pm 0.14$ & $1.01 \pm 0.20$ & $1.15 \pm 0.18$ & $1.08 \pm 0.24$ & $0.86 \pm 0.26$ \\
\hline
\end{tabular}

\subsubsection{Micromorphological features related to infolded clay structures}

In sink positions, the cryoturbated Bt clay layer shows several microfabrics of frost activity

(Van Vliet-Lanoë, 1998). Among these, there are thick (200-500 $\mu \mathrm{m})$ laminated, orangebrown clay coatings, frequently in sub-vertical position, as infillings of fissures parallel to the wall of the surrounding carbonate sand hollows (Fig. 9a). In addition, there are rounded or distorted fragments of thick clay coatings (Fig. 9b) that have been deformed and shattered by frost. Also vertical jacking of clasts in the carbonate sands (Fig. 9c), sub-horizontal elongated 
large pores ascribed to former ice lenses and, as well as shattered glauconite grains (Fig. 9d), that all point to frost-activity.
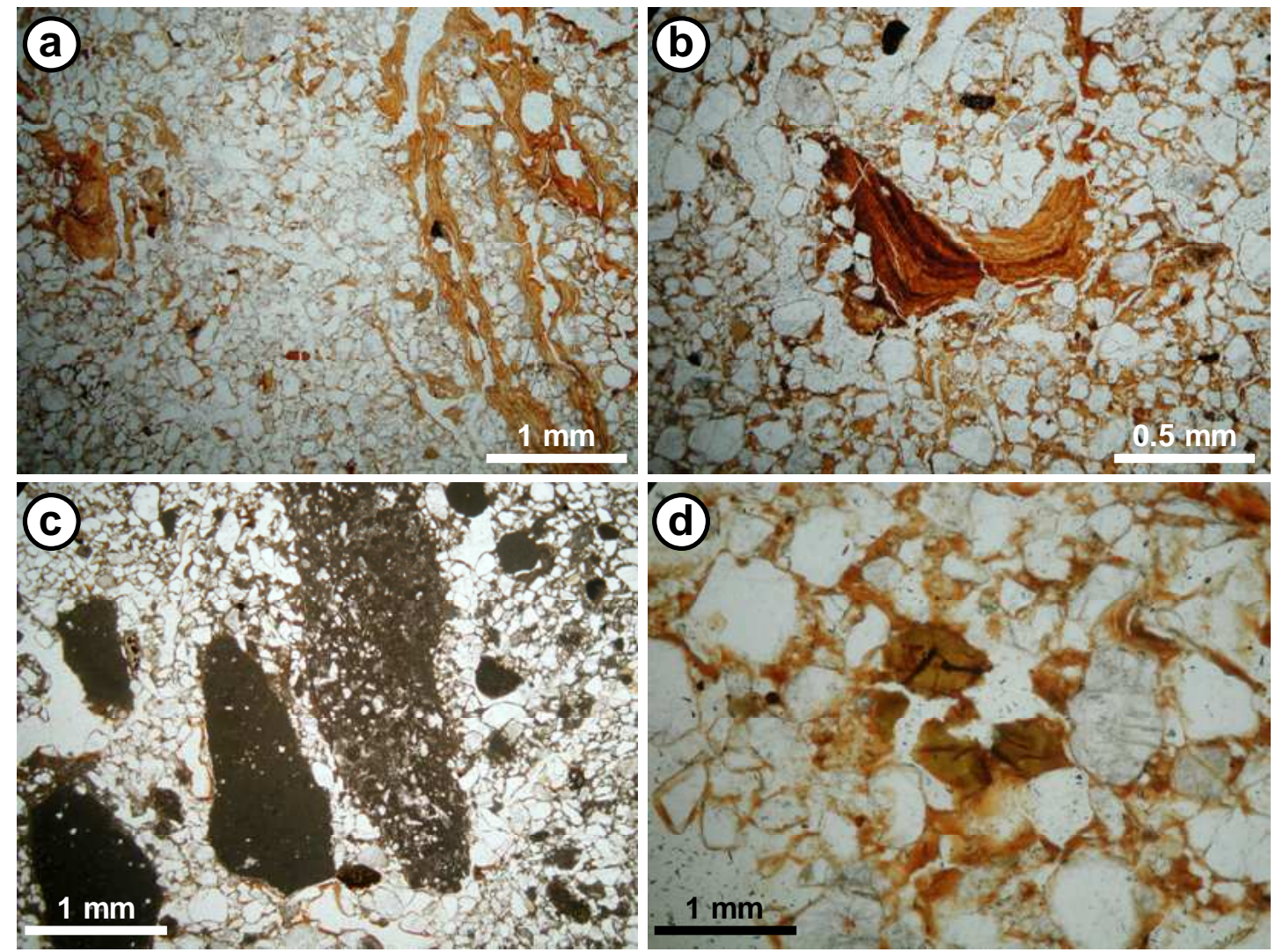

Figure 9 - Optical microscope images of cryogenic inheritage features in the Bt horizon. (a) - Clay illuviation along a sub-vertical fissure parallel to the sink structure. (b) - Fragment of thick clay illuviations. (c) - Vertical jacking of carbonate clasts. (d) - Frost shattered glauconite. Plane polarized light.

\section{$4 \quad$ Interpretation: Origin of the polygon patterns}

\subsection{General frame}

Decametric (15-30 m) regular polygonal structures are characteristic of cold regions with recurrent thermal contraction, known as patterned ground, frequently occurring in soils under continuous permafrost (e.g. Tedrow, 1977; Washburn, 1979; Romanovskii, 1985; Mackay, 1992). They are linked to the (peri)glacial periods of the Quaternary. Usually, thermal contraction proceeds when the substratum is rich in ice that accumulated from meteorological precipitation in the form of interstitial ice in porous rocks and segregation ice in fine material such as loess or clayey sands. Such ice accumulation usually proceeds in the upper horizons of the permafrost, between $50 \mathrm{~cm}$ and a dozen of metres at depth, with the highest accumulation just below the summer thaw average depth. Permafrost development comes also 
with frost shattering of the limestone and marls that produce fine particles (Lautridou, 1985), susceptible to increases the frost susceptibility of soils (Van Vliet-Lanoë, 1998).

The development of large polygonal patterns is initially linked to thermal cracking, further deformed by differential frost heaving (Pissart, 1970; Van Vliet-Lanoë, 1998), due to the capacity of fine sediment to retain moisture, to shrink following cryodesiccation, and to develop segregation ice in form of ice lenses (Taber, 1929; Pissart, 1970). The more the material contains fine particles, the later it will freeze due to its larger moisture content, and the more it will heave and be constrained by already frozen adjacent material, poorer in adsorbed and capillary water (Van Vliet-Lanoë, 1998).

\subsection{Successive landscape events}

The first event interpreted from the field evidence was the filling of depressions with green glauconitic sands. This may correspond to the infill of thawing hollows of a shallow polygonal network resulting from ice wedge casting (thermokarst depression), further deformed by cryoturbation processes during progressive thawing (Van Vliet-Lanoë, 2006). The green sands contain common limestone clast fragments that witness reworking of the sand by solifluction and deflation on the frost shattered marl and limestone, before infilling of the thawing hollows. The fragmented Marnes et Caillasses Limestone typically represents a frost shattered ground associated with permafrost, as currently observed in the high Arctic region. This is consistent with the occurrence of a line of vertically positioned clasts, related to frost jacking, a common feature in freezing grounds - even during temperate winters (Pissart, 1970).

The line of limestone clasts marks an erosional episode that followed the development of the green sand polygonal hollows. It probably represents frost debris forming a "desert pavement" and may be related to aeolian deflation leaving the coarse-sized debris at the surface.

The limestone clast layer preceded the deposition of the sandy material that forms the parent material of the $\mathrm{E}$ and $\mathrm{Bt}$ horizons. The sandy textured parent material of the $\mathrm{E}$ and $\mathrm{Bt}$ horizons contained no limestone debris and most probably issued from wind drift deposits. It was to a large part fed from the Beauchamp Sand Formation that crops out in local scarps, possibly with minor addition of loess and river sand of the neighbouring Oise River. Consecutively, the sand has been weathered with differentiation of two pedological horizons, a lower clayey Bt horizon and an upper sandy eluviated E horizon. Timing of this weathering can be assessed. Since the sink structures always showed a strict geometrical agreement with the 
overlying pedological layering of the E and Bt horizons, soil development occurred prior to the sinking event. If not, unweathered sand would be still present in the deepest and narrowest sink pockets. So, the $\mathrm{E}$ and $\mathrm{Bt}$ horizons appear as a palaeosol, even if pedological processes may have been re-activated in modern landscape.

The sink structures are related to thermal cracking, cryo-desiccation and the consecutive formation of ice veins (permafrost) within the superficial formations (up to 2 to $3 \mathrm{~m}$ depth). Consecutive to ice melting the clast lag and the $\mathrm{E}$ and Bt horizons were together dragged down in the melt hollows.

A last erosion episode evened out the inherited microreliefs and preceded the development of the present day soil features. Additionally, consistent anthropogenic surface levelling occurred at the end of the 19th century, when preparing the sandy surface soils of the plateaux to favour the gravitational spreading of huge volumes of waste water. Within the carbonate substrate, the Cca limestone accumulations post-date the morphologic processes since they are not deformed. This fits with recent ages from ${ }^{14} \mathrm{C}$ dating. Finally, the bow-like thin ironimpregnated layers that occur within the E horizon, appear as disharmonic with respect to the sink structures and thus also appear as more recent.

\subsection{Landscape chronology}

A timing schedule may be proposed considering the general knowledge of regional Quaternary glacial processes. The chronology is relatively well constrained for the latest landscape evolutions, but are more complex when extending back in time. Two successive cryoturbation events are imprinted in the soil trenches, and may be linked with two distinct glacial stages or to climatic fluctuations within the last glacial stage. Nevertheless, the erosion that occurred after development of the sand hollows appears as a major landscape shaping event: There is no longer direct input of glauconitic sand in the sections, obviously the scarp of the Sables de Beauchamp retreated suggesting that the erosion occurred over a longer time period, in between two glacial stages. Moreover, strong weathering affected the sandy deposits that followed the erosion phase, pointing to a longer mild climate during an interglacial stage.

Resuming, the chronology of the landscape and soil development may be extended backward starting from the Saalian glaciation (Fig. 10).

The first stage led to development of the ice wedge polygon, subsequently "cryoturbated" (Fig. 10a), most likely fits with a more humid and cold period, like MIS 8 
(Saalian I glaciation) c. $260 \mathrm{ka}$, corresponding to one of the southernmost extents of permafrost during Quaternary (Van Vliet-Lanoë and Hallégouët, 2001).

Erosion of the thermokarstic polygons, with formation of the limestone clast pavement, and followed by aeolian deposits probably occurred during the last part of the Saalian II glaciation. It is suggested that erosion occurred between 180-150 ka BP and wind drift deposited between 150-130 ka BP (Fig. 10b) prior to the Eemian interglacial (Seidenkrantz et al., 1996).

Weathering of the sand deposit developed during the Eemian interglacial (130$75 \mathrm{ka} \mathrm{BP}$ ), allowing the formation of clearly differentiated eluvial and illuvial pedogenic horizons (Fig. 10c, d). Illuviation features prove the existence of a well developed Luvisol on frost affected material which was further patchily illuviated with late argilo-humic illuviations. The soil developed in a steppic environment probably belonging to the early Weichselian (Van Vliet-Lanoë, 1986). Illuviations have later been strongly cryoturbated.

Development of the sink structures related to thermokarst phenomenon (Fig. 10e) could develop during the Pleniglacial optimum (Weichselian) c. 40-27 ka BP or early Late Glacial (14.6 ka).

The last erosion that levelled the periglacial microrelief (Fig. 10f) comes without any periglacial structure. It may coincide with the Late Glacial (Weischselian) which was less cold than previous stages. A date around c.15-10 ka BP may be suggested (Van VlietLanoë et al., 1992).

Pedological structures in discordance with sink structures, such as the secondary Cca limestone accumulation at depth, or the thin, bow-like iron-accumulated bands in the $\mathrm{E}$ horizon, relate to modern pedological evolutionary stages, most likely enhanced by repetitive water lodging due to intensive spreading of huge amounts of urban waste water for more than one century. The Ap horizon, although showing a comparable granulometric composition, appears as discordant with respect to the periglacial structures and $\mathrm{E}$ and $\mathrm{Bt}$ horizons, due to annual ploughing to a consistent depth and surface erosion due to gravitational flood irrigation. This Ap horizon contains anthropogenic compounds added by waste water (organic matter, secondary carbonates) and additional urban organic waste inputs, such as plastics, ceramics, glass, oyster shells, fishbone, etc. 

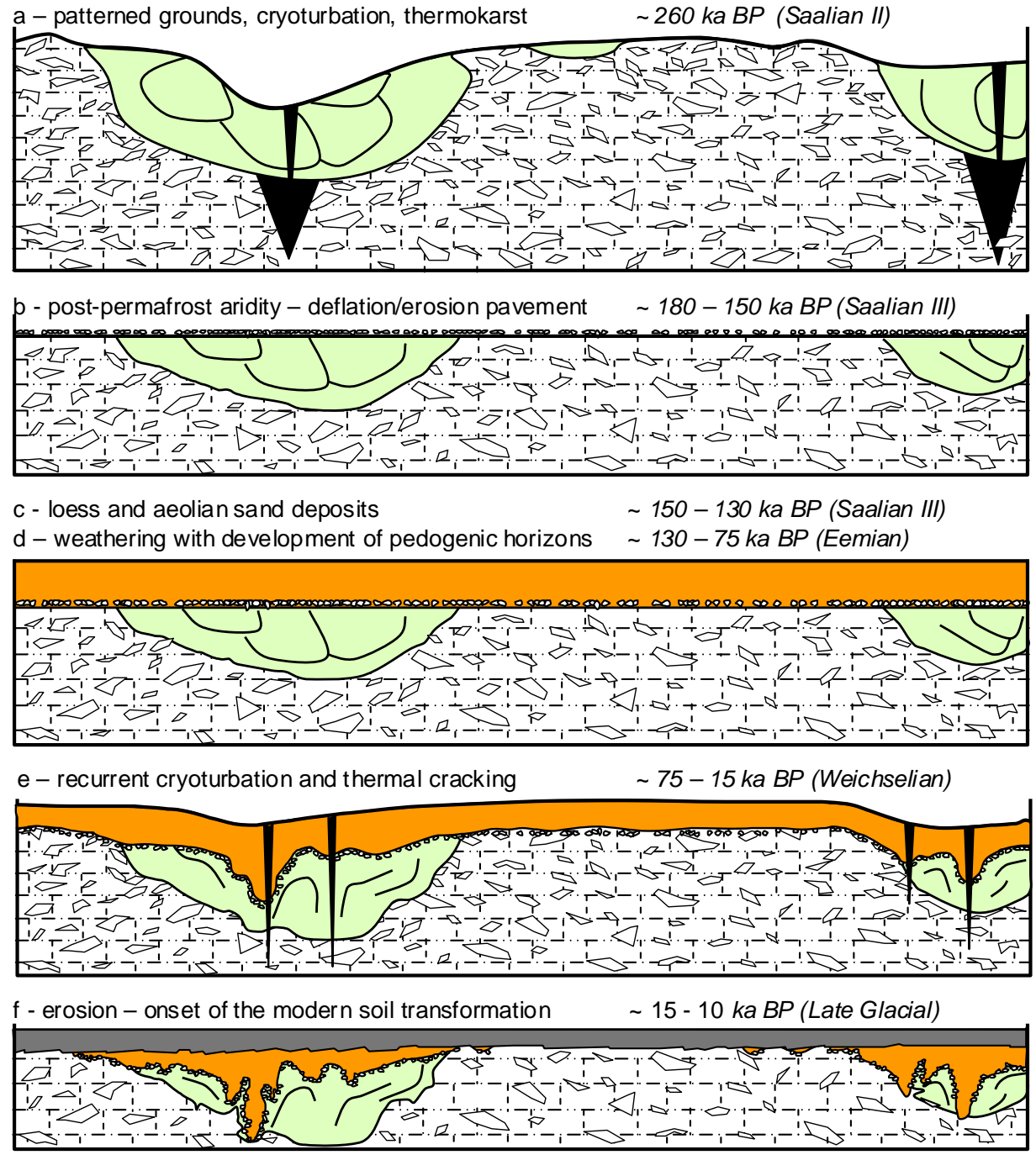

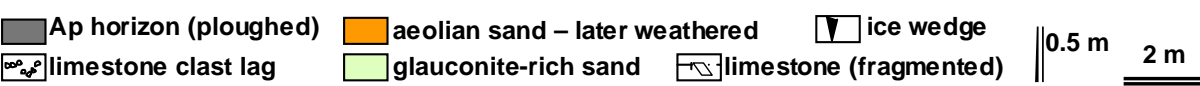

Figure 10 - Chronological sequence of glacial morphogenesis giving birth to the development of pedological structures and soil profiles in the Pierrelaye-Bessancourt area.

\section{$5 \quad$ Consequences for soil management}

\subsection{Heavy metal soil pollution}

At the end of the $19^{\text {th }}$ century, the improvement of managing urban waste was operated in Paris and its suburbs, notably by collecting waste water and spreading huge volumes on restricted areas, mainly coarse textured, poorly fertile soils, instead of their direct return to the Seine River. For this, four irrigated areas located W of Paris were selected, totaling about 5000 ha at the beginning of the $20^{\text {th }}$ century (Védry et al., 2001). Discharging sewage water onto farm lands had the double advantage of eliminating urban waste and improving unfertile sandy soils. This latter practice was recognized as highly beneficial for agricultural land use as soon as 1895 (Risler, 1897). Average annual rates of wastewater added at the surface of 
these soils were estimated at $2000 \mathrm{~mm}$ (Védry et al., 2001), in addition to a mean annual precipitation of $630 \mathrm{~mm}$. After sedimentation of the major part of suspended matter in the Ap horizon, large amounts of wastewater drained trough the soils and were evacuated toward the calcareous substrate.

However, a hundred years of considerable irrigation with of urban waste water led to high levels of heavy metals ( $\mathrm{Zn}, \mathrm{Pb}, \mathrm{Cu}$, and $\mathrm{Cd}$ ) in the surface horizon of these soils (Lamy et al., 2006; van Oort et al., 2008). Food crop production was stopped by public authorities in 1999 . Soil studies were undertaken to conceive proposals for stabilization or rehabilitation of such long-term irrigated sites. In this view, it was necessary to assess the amounts of metals stored in the soils, their fate, and hence to determine their repartition in the different soil horizons.

A first pedogeochemical soil survey campaign, based on soil auger drilling and examination of soil pits, revealed a great variability of soil depth and contrasting situations with local zones with thicker and deeper clay-rich horizons (Fig. 11). These zones intercepting metal pollutants, notably Zn, were interpreted as sinkholes and zones of preferential infiltration of polluted soil solutions (van Oort et al., 2008).

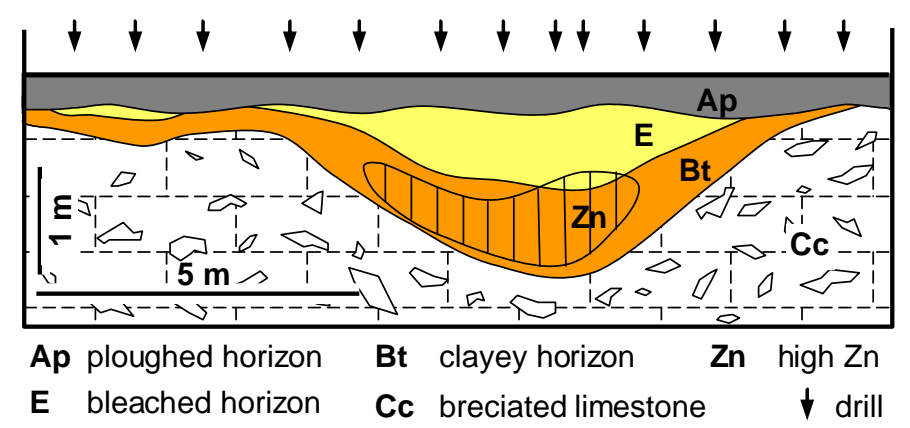

Figure 11 - Soil horizon dispositions in the polluted area as recognized by auger drill survey. The deeper and thicker clayey horizons appear as layers intercepting and accumulating migrating metal pollutants, notably dissolved $\mathrm{Zn}$.

\subsection{Polygonal patterns and metal pollutant mobility}

Revealing cryogenic polygonal structures in the soil cover required a new view on the hydrological behaviour of these soils. The presence of the large-scale cryogenic structures in subsurface soil horizons implied major contrasting hydrodynamic conditions over small distances with localized impacts on the fate of metal pollutants. The cores of the polygonalshaped structures occupy about 60 to $70 \%$ of the land surface and represent zones where the Ap horizon either directly overlies the Cc limestone, or is separated from it only by a reduced thickness of the Bt horizon. The fragmented limestone is highly permeable and most of the wastewater that crosses the Ap horizon is preferentially evacuated to the substrate through 
these zones. By contrast, at the location of the infolded clay structures, the drainage of gravitational water is strongly limited (Fig. 12) due to the low permeability of the dense clay bodies. Moreover, such clay bodies intercept a large part of dissolved and/or colloidal metal pollutants still present in the draining soil solution that stagnates above the clay structures (Citeau, 2004). Finally, the clay-rich sink structures play a protecting role for the surrounding calcareous substrate from wastewater inflow.

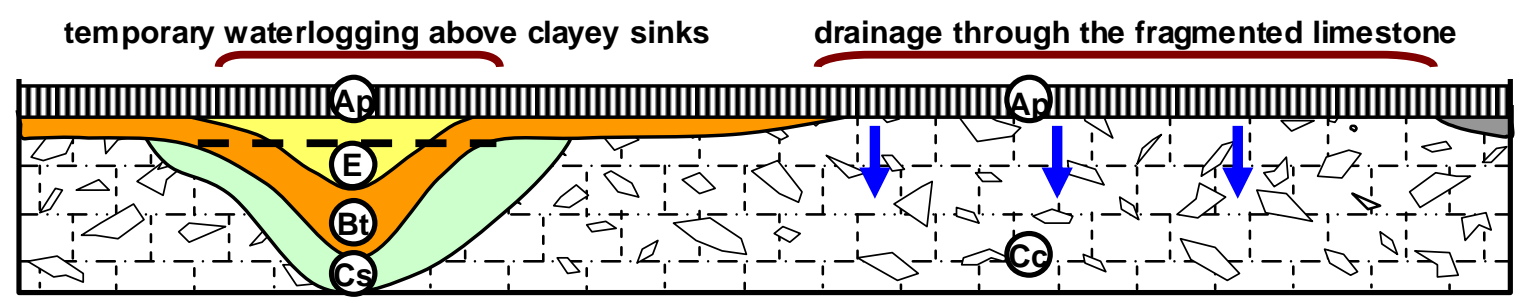

Figure 12 - Sketch of the contrasted drainage behaviour between the centre of the cryogenic structures and their peripheral clayey sink structures. Sink structures are mainly waterlogged and retain the heavy metal pollutants, whereas the core of the polygons formed of blocky limestone, favourable to dispersion of metal pollutants into the substrate and down to water table.

Colloidal organic matter represents a major vector of metal pollutants toward soil depth. Sand grains most often have a negligible contribution to the retention of colloids in regard to fine mineral soil fractions, such as clay and iron oxides that represent the main active trapping constituents for metal pollutants in soils (McBride et al., 1997; van Oort et al., 2006, 2008) as well as for organic pollutants (Tamtam et al., 2011). In this regard, we compared the Zn contents of the "reactive" fine fractions in two contrasting positions with respect to the polygonal structures, by attributing total $\mathrm{Zn}, \mathrm{Pb}$, and $\mathrm{Cu}$ concentrations determined on soil bulk samples to the fine $(<50 \mu \mathrm{m})$ groundmass granulometric fraction. Such mean calculated metal concentrations of $<50 \mu \mathrm{m}$ fractions from 33 collected samples in Cc and Cs layers revealed contrasting trends (Fig. 13).

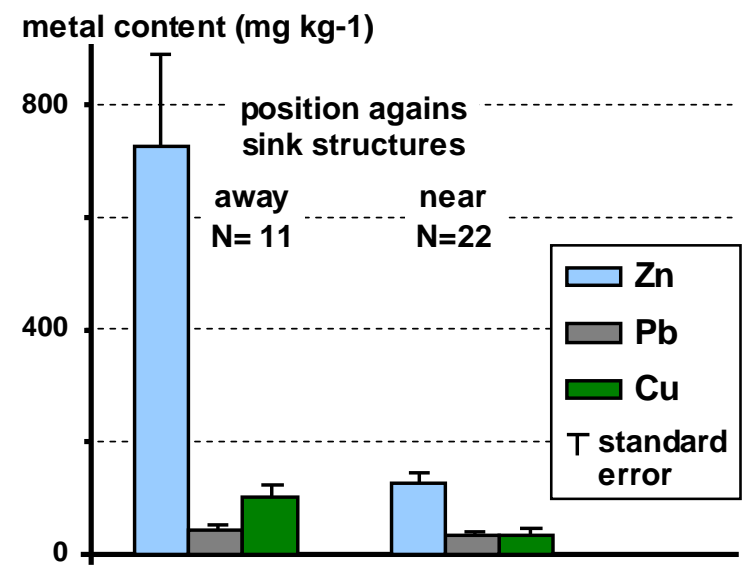

Figure 13 - Average $\mathrm{Zn}, \mathrm{Pb}$, and $\mathrm{Cu}$ contents calculated for $<50 \mu \mathrm{m}$ soil fractions (i.e. after subtracting of $\mathrm{CaCO}_{3}$ and sand grains), from samples collected in $\mathrm{Cc}$ and $\mathrm{Cs}$ material in trenches. 
The $\mathrm{C}$ layers were sampled at different depths near sink structures $(<1 \mathrm{~m})$ and away from the sink structures. For $\mathrm{Zn}$, the average $\mathrm{Zn}$ contents of the $<50 \mu \mathrm{m}$ fractions of $\mathrm{C}$ material near clayey infoldings were significantly less than those observed in the absence of a clayey horizon. For $\mathrm{Pb}$, little or no effect was observed, but for $\mathrm{Cu}$, the amount in the $\mathrm{C}$ layer with a reduced developed clay $\mathrm{Bt}$ horizons was about threefold larger than in the presence of a $\mathrm{Bt}$ horizon. These findings clearly highlight the metal pollutant transfer in the zones with a reduced or lacking $\mathrm{Bt}$ horizon.

\section{Conclusion}

Geophysical survey of the Pierrelaye soil cover, applied in the first place to map the spatial extent of 'metal interception' clay horizons at depth, revealed remarkable, unexpected conductive structures, forming polygon patterns of about $20-30 \mathrm{~m}$ in diameter, detected between 0.5 and $1.7 \mathrm{~m}$ depth. Such structures were interpreted as a buried polygonal icewedge net (thermokarst depressions), related to Quaternary (peri)glacial periods. The towed Automatic Resistivity Profiling (APR ${ }^{\odot}$ ) method was revealed to be particularly well-adapted to revealing such structures: one-day mapping of a $150 \mathrm{~m}$-wide and $1000 \mathrm{~m}$-long farmland strip provided good insight on the spatial distribution and continuity of such cryogenic structures, usually impossible to observe in ancient formations. Detailed analysis of the structure geometry and their mutual relations, studied in trenches located across the polygon structures, as well as of erosion unconformities and weathering features allowed unravelling of characteristics of landscape setting over time and to propose a chronology of the periglacial morphogenetic events that affected the area. Our reconstruction highlighted relative landscape stability during the Saalian and Weichselian glacial periods. With respect to present-day soil behaviour, the polygonal cryogenic structures strongly influence soil hydrology, resulting in contrasted hydrodynamic conditions. Cryoturbated clay sink structures act as almost impermeable zones, whereas the infiltration zones correspond to the fragmented limestone zones. Distribution of heavy metal contents in the fine earth fraction of the fragmented limestone were found to be consistent with such hydrological conditions. The fine earth of the limestone occurring around the clayey sink structures contained significantly lower heavy metal than the fine earth of the limestone zones not overlain by a clay-rich horizon. The Pierrelaye urban wastewater irrigation area offered a good illustration of how millennial-scale geomorphological structures may affect the fate of merely one century old anthropogenic micro-pollutants in soils. Our work showed that comprehensive soil survey of such cryogenic 
structures is of prime importance for a thorough understanding and modelling of hydrological behaviour of soils.

Acknowledgement: The authors are grateful to the GEOCARTA SA team who made the geophysical survey. They thank all persons of the Pessac-INRA team, Sisyphe-CNRS group and the Geosciences Mines-ParisTech team who took part in section description and sampling during a cold and rainy week in November 2008. This work was granted by financial support of the Conseil Régional de l'Ile-de-France (CRIdF), the Conseil Général du Val d'Oise (CG95), the Agence de l'Eau de Seine-Normandie (AESN) and the Syndicat Interdépartemental pour l'Assainissement de l'Agglomération Parisienne (SIAAP). The Authors wish to thank A. Makeev from Moscow State University and two anonymous reviewers how contributed to improve an early version of the manuscript, as well as Prof. A.J. Plater from Liverpool University for editing the manuscript..

\section{References}

Allard, M., Kasper, J.N., 1998. Temperature conditions for ice-wedge cracking; field measurements from Salluit, northern Quebec. Permafrost, Seventh International Conference, Proceedings, Yellowknife, NWT, Canada, 5-12.

Bourennane, H., Dère, C., Lamy, I., Cornu, S., Baize, D., van Oort, F., King, D., 2006. Enhancing spatial estimates of metal pollutants in raw wastewater irrigated fields using a topsoil organic carbon map predicted from aerial photography. Science of the Total Environment, 361 (1-3), 229-248. doi: 10.1016/j.scitotenv.2005.05.011

Citeau, L., 2004. Etude des colloïdes naturels circulant dans les eaux gravitaires de sols contaminés : nature des colloïdes et réactivité vis-à-vis des métaux. Doctoral thesis, INAPG, Paris-Grignon.

Dabas, M., 2008. Theory and practice of the new fast electrical imaging system ARP@. In: Seeing the Unseen, Geophysics and Landscape Archaeology, Piro S. and Campana S., eds., CRC Press, Taylor and Francis Group, 105-126. doi: 10.1201/9780203889558.

Dère, C., Lamy, I., van Oort, F., Baize, D., Cornu, S., 2006. Reconstitution des apports en éléments traces métalliques et bilan de leur migration dans un Luvisol sableux soumis à 100 ans d'irrigation massive par des eaux usées brutes. Comptes Rendus Géoscience, 338 (8), 565-573.

Dylik, J., Maarleveld, G.C, 1967. Frost craks, frost fissures and related polygons. Mededeling van de Geologische Stichting, Nieuwe série, 18, 7-21.

Lachenbruch, A.H., 1962. Mechanics of the thermal contraction cracks and ice-wedges polygons in permafrost. Geol. Soc. Amer., Spec. Paper, 70, 69 p. 
Lamy, I., van Oort, F., Dère, C., Baize, D., 2006. Use of major- and trace-element correlations to assess metal migration in sandy Luvisols irrigated with wastewater. European Journal of Soil Science, 57 (5), 731-740. doi: 10.1111/j.1365-2389.2005.00765.x.

Lautridou, J.P., 1985. Le cycle périglaciaire pléistocène en Europe du Nord-Ouest et plus particulièrement en Normandie. Thèse Doc. es Lettres, Edition Centre de Géomorphologie du CNRS, Caen, 907 p.

Mackay, J.R., 1992. The frequency of ice-wedge cracking (1967-1987) at Garry Island, western Arctic coast, Canada. Canadian Journal of Earth Sciences, 29 (2), 236-248, doi: 10.1139/e92-022.

McBride, M.B., Richards, B.K., Steenhuis, T., Russo, J.J., Sauvé, S., 1997. Mobility and solubility of toxic metals and nutrients in soil fifteen years after sludge application. Soil Science, 162 (7), 487-500. doi: 10.1016/S0269-7491(98)00011-6.

van Oort, F., Jongmans, A.G., Citeau, L., Lamy I., Chevallier, P., 2006. Microscale Zn and Pb distribution patterns in subsurface soil horizons: an indication for metal transport dynamics. European Journal of Soil Science, 57 (2), 154-166. doi: 10.1111/j.13652389.2005.00725.x.

van Oort, F., Lamy, I., Baize, D., Jongmans, A.G., Chevallier, P., 2008. Impacts of long-term waste-water irrigation on the development of sandy Luvisols: consequences for metal pollutant distributions. European Journal of Soil Science, 59 (5), 925-938.

doi: 10.1111/j.1365-2389.2008.01047.x

van Oort, F., Thiry, M., Foy, E., Fujisaki, K., van Vliet-Lanoë, B., 2013. Pédogenèse polyphasée et transferts de polluants métalliques contraints par des structures cryogéniques - le cas des sols sous épandages massifs d'eaux usées dans la plaine agricole de Pierrelaye. Etude \& Gestion des Sols, 20 (1), 7-26.

Pissart, A., 1970. Les phénomènes physiques essentiels liés au gel, les structures périglaciaires qui en résultent et leur signification climatique. Annales de la Société géologique de Belgique, 93 (1), 7-49.

Risler, E., 1897. Géologie Agricole, IV, Berger-Levrault Imprimerie, Nancy, France.

Romanovskii, N.N., 1985. Distribution of recently active ice and soil wedges in the USSR. in Field and theory - lectures in Geocryology, M.Church and O. Slaymaker, eds, University of British Columbia Press, Vancouver, 154-165.

Seidenkrantz, M.-S., Bornmalm, L., Johnsen, S.J., Knudsen, K.L., Kuijpers, A., Lauritzen, S.E., Leroy, S.A.G., Mergeal, I., Scweger, C., van Vliet-Lanoë, B., 1996. Two-step deglaciation at the oxygen isotope stage 6/5e transition: the Zeifen-Kattegat climatic oscillation. Quaternary. Science Reviews, 15 (1), 63-75. doi.org/10.1016/02773791(95)00086-0

Tabbagh, A., Dabas, M., Hesse, A., Panissod, C., 2000. Soil resistivity a non-invading tool for soil structure characterisation. Geoderma, 97 (3-4), 393-404. doi.org/10.1016/S00167061(00)00047-1 
Taber, S., 1929. Frost heaving. Journal of Geology, 37 (5), 428-461. doi:10.1086/623637. Tamtam, F., van Oort, F., LeBot, B., Dinh, T., Mompelat, S., Chreveuil, M., Lamy, I., Thiry, M., 2011. Assessing antibiotic contamination in metal contaminated soils four years after cessation of long-term waste water irrigation. Science of the Total Environment, 409 (3), 540-547. doi: 10.1016/j.scitotenv.2010.10.033.

Tedrow, J.J.C.F., 1977. Soils of the polar landscape. Rutgers Univ. Press, New Brunswick, N.J., 638 p.

Thiry, M., van Oort, F., Lamy, I., Thiesson, J., Tabbagh, A., Tamtam, F., 2011. Etude d'évaluation du risque de mobilité des métaux dans l'agrosystème contaminé de Pierrelaye-Bessancourt : prospections du site, fonctionnement des sols et tests de lixiviation. Rapport technique No R111125MTHI, Centre de Géosciences, Ecole des Mines de Paris, Fontainebleau, France, 169 p.

Van Vliet-Lanoë, B.,1998. Frost and soils: implications for paleosols, paleoclimates and stratigraphy. Catena, 34, 157-183.

Van Vliet-Lanoë, B., 2006. Deformations in the active layer related with ice/soil wedge growth and decay in present day arctic. Paleoclimatic Implication. Annales de la Société Géologique du Nord, 12 (1), 81-95.

Van Vliet-Lanoë, B., 1986. Le pédocomplexe du dernier Interglaciaire (de 125000 à 75000 BP). Variations de faciès et signification paléoclimatique, du sud de la Pologne à l'ouest de la Bretagne. Bull. A.F.E.Q.,1-2, 139-150.

Van Vliet-Lanoë, B., Hallégouët, B, 2001. European permafrost at the LGM and at its Mmaximal extent. The Geological Approach. In: Permafrost Response on Economic Development, Environmental Security and Natural Resources, R.Paepe and V. Melnikov, eds, Kluwer Academic Publisher, Dordrecht, The Netherlands, 195-213. Van Vliet-Lanoë, B., Fagnart, J.P., Langohr, R., Munaut, A, 1992. Evolution écopédologique et morphopédologique du sol lessivé de surface dans les lœss d'Europe occidentale: argumentation stratigraphique et archéologique. Science du Sol, 30 (2), 75- 93.

Védry, B., Gousailles, M., Affholder, M., Lefaux, A., Bontoux, J., 2001. From sewage water treatment to waste water reuse. One century of Paris sewage farms history. Water Science and Technology, 43 (10), 101-107.

Washburn, A.L., 1979. Geocryology - A survey of periglacial processes and environment. Arnold Publications, London, 406 p. 